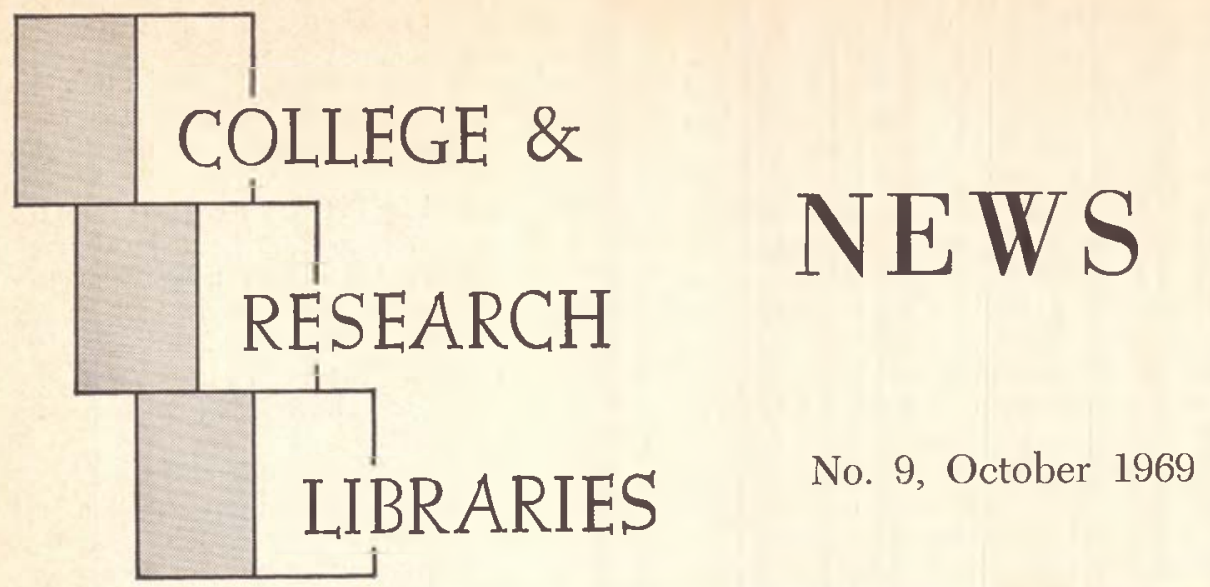

ACRL News Issue (B) of College \& Research Libraries, Vol. 30, No. 5

\title{
ACRL Report to Council, 1968/69
}

JUNE 1969

Event of the year in ACRL was the departure of one Executive Secretary and the advent of another. George M. Bailey, after having served admirably in this office for five eventful years, removed in August to the librarianship of York College of the City University of New York. After a three-month hiatus during which we were well looked after by more members of the Headquarters staff than could be enumerated here, J. Donald Thomas, former associate librarian at the University of Chicago, took over the post with a will and a vigor that have served us well in the latter eight months of the year. Looking back upon this transition, we feel we came out of it in excellent condition; there were times during the experience, however, when we feared we would not.

The main work of this Association was conducted throughout the year by its Committees, Publications, and Sections. The balance of this report will discuss their several activities.

\section{Committees}

Under the able chairmanship of A. P. Marshall, the Audio-Visual Committee moved forward with its current main preoccupation, the compilation of a handbook of guidelines for college libraries which plan to institute or reorganize their audio-visual services. By year's end this major task was moving rapidly toward early completion.

The Committee on Community Use of Academic Libraries, chaired by E. J. Josey, com- pleted analyzing responses to its extensive survey of community use of junior college libraries and began the preparation of its report for publication.

Guided by chairman John P. McDonald, the Committee on Cooperation with Educational and Professional Organizations continued its good work of establishing personal contact with such varied agencies as the American Council of Learned Societies, the Engineers Joint Council, and the Asia Foundation, and of acquainting their officers with the programs, purposes, priorities, and prospects of ACRL.

Now completing its fourteenth year, the Committee on Grants accomplished its traditional task of distributing small sums to college libraries, totalling this year some $\$ 63,550$ to seventy-six institutions. In addition, chairman H. Vail Deale led the group through a salutary period of self-scrutiny in an effort to rationalize the grants program in accord with several recent modifications in the environment in which it functions.

Past President Katharine M. Stokes' Committee on Library Services at midyear handed over to the recently established AASL/ACRL Committee on Instruction in the Use of $\mathrm{Li}$ braries its concern for student library orientation and began addressing itself to extended service possibilities inherent in the development of library networks.

Major among the year's concerns for the Publications Committee was the identification of nominees for the editorships of three of the As- 
sociation's four publication series: College \& Research Libraries, the Monograph Series, and the Microform Series. Chairman Mark Gormley reports that all three changes in editorship have now been successfully negotiated.

The Committee on Standards found itself moving major projects ahead on three fronts: (1) revision of the Standards for Junior College Libraries; (2) revision of the Standards for College Libraries; and (3) an approach jointly with the Association of Research Libraries to the problems of standards for university libraries. Veteran chairman Norman Tanis indicates substantial progress on all three tasks.

The Joint AAC-ACRL Committee on College Libraries, under the chairmanship of Richard Harwell, converted its previous occasional circular letter on library problems to college presidents into a full-fledged periodical, College $\mathrm{Li}$ brary Notes. Initial reaction to this new periodical, which is prepared by ACRL and published by the Association of American Colleges, has indeed been gratifying. Also in the course of the year the AAC sought ACRL advice in several other library matters through this joint committee.

The Joint AASL-ACRL Committee on Instruction in the Use of Libraries, with James F. Govan in the chair, concentrated its efforts on the problem of educating college students preparing for careers in teaching in better methods of library utilization for instructional purposes.

Expert Service on

MAGAZINE SUBSCRIPTIONS for

ALL LIBRARIES

FAXON LIBRARIAN'S GUIDE

available on request

Fast, efficient, centralized service for over 80 years. Library business is our only business!

\section{F. W. FAXON CO., INC. \\ 15 Southwest Park}

Westwood, Mass. 02090

Continuous Service to Libraries Since 1886

\section{Publications}

The Association maintains four serial publications, Choice, College \& Research Libraries, ACRL Microform Series, and ACRL Monograph Series.

Choice, edited by Peter Doiren, was founded five years ago under a grant from the Council on Library Resources and is now completely self-supporting. Some 5,600 reviews appeared in its most recent volume, done by about 2,500 reviewers. Subscriptions rose 10 per cent during the past year, and advertising revenue increased 40 per cent.

College \& Research Libraries, which I edit, is now in its thirtieth year of publication and currently appears in seventeen issues annually. It too is self-supporting. It utilized more pages of type in 1968-69 than ever before. Although Publications Officer Mary Falvey left ACRL proper during the year, she continued her good service as Managing Editor of CRL through her new assignment as head of ALA's Central Production Unit.

ACRL Microform Series under the editorship of Felix Reichmann revised its format, scope, and production contract during the year and ended the season at least as healthy as it began. Now appearing in microfiche rather microcard, this series publishes theses, reports, and other documents of interest to the academic library community.

ACRL Monograph Series, under editor David Heron, produced two new publications in 1968. 69 , prepared two others for publication, and accepted a fifth. Well over thirty monographs have now appeared over this imprint since its establishment.

\section{Sections}

Much of ACRL's work is conducted through its vigorous Sections, of which there are five: the College Library Section, the Junior College Library Section, the Rare Books Section, the Subject Specialists Section, and the University Library Section.

The College Library Section, currently chaired by Evan Ira Farber, accomplished advances in the areas of library instruction to students, in presenting the college library "message" to several library school student bodies, and in developing better understanding of nonWestern resources for undergraduate study.

The Junior College Library Section, which Shirley Edsall has chaired, worked in several ways on the problems of multi-media use in junior colleges, guided the Junior College $\mathrm{Li}$ braries Information Center of ALA to its completion in May, and urged funding of its projects to survey current library practices and to establish demonstration libraries in junior colleges.

The Rare Books Section, J. M. Edelstein, 
chairman, restructured itself so as to accommodate the interests of a substantial number of old and new members of the Section concerned with manuscripts and archives in general libraries. It also continued its traditional liaison with the Bibliographical Society of America by planning a joint meeting with it near the Atlantic City Conference.

The Subject Specialists Section works primarily through its six Subsections, each of which comprises a close-knit body of specialistlibrarians who find in their Subsection a focus for their professional energies and concerns. Chairman Thomas D. Gillies reports that the newest of these valuable subdivisions, the Asian and North African Subsection, has moved rapidly into a dynamic program of professional activities which will be a source of considerable new strength to the Association.

The University Library Section, which is chaired by G. F. Shepherd, Jr., is able to report some meaningful progress in its efforts to resolve certain problems in the areas of appropriate status for university librarians, of university libraries in urban settings, and of extension services in universities.

\section{Conclusion}

In conclusion, I am pleased to report that this 14,000-member Association has had a good year. We close it with three unresolved problems which are beyond our ability to conclude, and we commit them to ALA in hopes of prompt attention to them. They are:

1) the inappropriateness of ACRL's Subject Specialists Section to any existing division of ALA and our recommendation that it be reconstituted as a division in its own right;

2) the inadequacy of present ACRL staff in ALA Headquarters to meet the needs of this Association;

3 ) the need to remove the moratorium imposed last year on new activities, which will in our judgment throttle in a very short time what has been a vigorous, growing organization in a dynamic professional society.

We are confident that these three matters can be resolved to the mutual benefit of this Association and ALA.

-David Kaser, President Association of College and Research Libraries 26 May 1969

ACRL Membership August 31, 1969

August 31, 1968

August 31, 1967 12,060

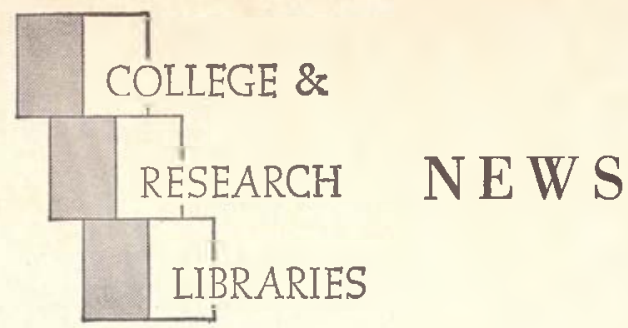

ACRL News Issue of College \& Research Libraries

Editor, Richard M. Dougherty, University of Colorado Libraries, Boulder, Colorado 80302.

News Editor, Michael Herbison, Casper College, Casper, Wyoming 82601.

Editorial Board: Richard DeGenNaro, Harvard University; DAvid Heron, University of Kansas; EllswORTh Mason, Hofstra University; FRED HeINRITZ, Southern Connecticut State College; William Axford, Florida Atlantic University; PETER Hiatr, Indiana University.

ACRL Officers, 1969/70: President, Philip J. McNiff; Chairman, College Libraries Section, John E. Scott; Junior College Libraries Section, Ruthe Erickson; Rare Books Section, Robert J. Adelsperger; Subject Specialists Section, Marcia J. Miller; Agriculture and Biological Sciences Subsection, Howard Rovelstad; Art Subsection, Wolfgang M. Freitag; Educational and Behavioral Science Subsection, Donald Leatherman; Law and Political Science Subsection, Roy M. Mersky; Slavic and East European Subsection, Joseph Placek; University Libraries Section, Roscoe Rouse.

News from the Field, Personnel profles and notes, classifed advertising, official matter of ACRL, and other material of a timely nature is published in the News issues of College \& Research Libraries.

Inclusion of an article or advertisement in CRL does not constitute official endorsement by ACRL or ALA.

Production and Advertising and Circulation office: 50 E. Huron St., Chicago, Ill. 60611. Change of address and orders for subscriptions should be addressed to College ir Research Libraries, for receipt at the above address, at least two months before the publication date of the effective issue.

Subscription to $C R L$ is included in membership dues to $A C R L$ of $\$ 6$ or more; other subscriptions to $C R L$ are $\$ 10$ per year. Neither subscriptions nor memberships include miscellaneous unscheduled supplements, which are available by purchase only. Retroactive subscriptions are not accepted. Single journal copies are avail able at $\$ 1.50$ each and News issues at $\$ 1.00$ each from ALA Publishing Department.

Indexed in Library Literature. Abstracted in Library Science Abstracts. Book reviews indexed in Book Review Index.

College of Research Libraries is the official journal of the Association of College and Research Libraries, a division of the American Library Association; and is published seventeen times per year-bi-monthly as a technical journal with 11 monthly News issues, combining July-August-at 1201-05 Bluff St., Fulton, Mo. 65251 .

Second-class postage paid at Fulton, Mo. 